\title{
Macrophage migration inhibitory factor and DJ-I in gastric cancer: differences between high-incidence and low-incidence areas
}

\author{
NJ Shimwell,5, DG Ward',5, Y Mohri ${ }^{2}$, T Mohri ${ }^{3}$, L Pallan', M Teng', YC Miki ${ }^{4}$, M Kusunoki ${ }^{4}, 0$ Tucker', \\ W Wei', J Morse' and PJ Johnson*,I
}

'Cancer Research UK School of Cancer Sciences, University of Birmingham, Vincent Drive, Edgbaston, Birmingham BI5 2TT, UK; ${ }^{2}$ Department of Innovative Surgery, Graduate School of Medicine, Mie University, 2-1 74, Edobashi, Tsu, Mie 5 I 4-8507, Japan; ${ }^{3}$ Department of Surgery, Toyama Hospital, 17-22. Minami-Schinmachi, Tsu, Mie 514-0043, Japan; ${ }^{4}$ Department of Gastrointestinal and Pediatric Surgery, Graduate School of Medicine, Mie University, 2-174, Edobashi, Tsu, Mie 5/4-8507, Japan

\begin{abstract}
BACKGROUND: There is a need for sensitive and specific blood-borne markers for the detection of gastric cancer. Raised serum macrophage inhibitory factor (MIF) levels have been proposed as a marker for gastric cancer diagnosis but, to date, studies have only encompassed patients from high-incidence areas.

METHODS: We have compared the serum concentration of MIF in a large cohort of UK and Japanese gastric cancer patients, together with appropriate control subjects (age and gender matched). Carcinoembryonic antigen and H. pylori lgG were also measured, as was DJ-I, a novel candidate protein biomarker identified by analysis of gastric cancer cell line secretomes.

RESULTS: Marked elevations of the serum concentration of MIF and DJ-I were seen in Japanese patients with gastric cancer compared with Japanese controls, a trend not seen in the UK cohort. These results could not be accounted for by differences in age, disease stage or $\mathrm{H}$. pylori status.

CONCLUSION: In regions of high, but not low incidence of gastric cancer, both MIF and DJ-I have elevated serum concentrations in gastric cancer patients, compared with controls. This suggests that differing mechanisms of disease pathogenesis may be at play in high- and low-incidence regions.
\end{abstract}

British Journal of Cancer (2012) 107, 1595-1601. doi:10.1038/bjc.2012.405 www.bjcancer.com

Published online II September 2012

(c) 2012 Cancer Research UK

Keywords: MIF; DJ-I; geographical differences; gastric cancer

China, Japan and Korea exhibit the highest incidence rates of gastric cancer with over 40 cases per 100000 in males and 20 per 100000 in females (Jemal et al, 2007). By contrast, rates are lower in the West. In the United Kingdom, for example, comparable figures are 13 and 8 per 100000 , respectively, and have been falling steadily for more than 50 years (Jemal et al, 2007). The reason for the difference remains unknown but environmental factors appear to be important, as incidence rates in Japanese-born subjects fall when they relocate to lower incidence areas (Alberts et al, 2003). Treatment of gastric cancer remains a major area of unmet need with localised disease showing $62 \% 5$-year survival, decreasing to $22 \%$ following spread to regional lymph nodes and only 3\% with distant organ metastases (Jemal et al, 2007). Diagnosis requires upper gastrointestinal endoscopy, a procedure that consumes extensive resources and only a small minority of patients who undergo endoscopy when cancer is considered in the differential diagnosis have a final diagnosis of malignancy. A blood test that would permit prioritisation of those at risk would be valuable but to date no test is routinely available.

We and others have recently suggested that measurement of serum macrophage inhibitory factor (MIF) concentrations might fulfil such a role. Markedly elevated levels have been reported in

\footnotetext{
*Correspondence: Professor PJ Johnson; E-mail; p.johnson@bham.ac.uk ${ }^{5}$ These authors contributed equally to this work.

Received 8 May 2012; revised 7 August 2012; accepted 8 August 2012; published online II September 2012
}

China, Japan and Turkey (He et al, 2006; Camlica et al, 2008; Mohri et al, 2009), all areas of the world where the incidence of gastric cancer is high. In this prospective study, we investigated serum levels of MIF in patients with gastric cancer both in Japan and the United Kingdom. In both populations, we used 'real-world' control subjects, that is, those in whom gastric cancer was considered as part of the differential diagnosis but who had no evidence of malignancy on endoscopy. Additionally, DJ-1 was measured in the same sample cohort as we have identified it, along with MIF to be secreted by gastric cancer cell lines. Altered functionalitity of DJ-1 can have a profound effect on cellular biology. Defects in the DJ-1 gene (deletions and mutations) have been shown to be a contributing factor of autosomal recessive early-onset Parkinsons disease in both Chinese (Guo et al, 2008) and European (Bonifati et al, 2003) populations, whereas overexpression confers a cellular survival advantage and has been reported in prostate, ovarian, lung and breast cancer. DJ-1 has been shown to enhance cellular transformation in co-operation with H-Ras (Nagakubo et al, 1997). Negatively regulated by p53, with which it interacts, DJ-1 expression is partly increased through loss of p53 during transformation. DJ-1 can also protect cells from oxidative stress (Taira et al, 2004; Vasseur et al, 2009; Mo et al, 2010). Carcinoembryonic antigen (CEA) was also measured as a standard marker of gastrointestinal cancer (Ishigami et al, 2001) and because it has been reported that when CEA is combined with MIF, there is an enhancement of diagnostic utility (Camlica et al, 2008). The serum level of antibodies produced in response to 
H. pylori infection (H. pylori IgG) were also measured, as $H$. pylori has previously been shown to stimulate the release of MIF (Xia et al, 2005).

\section{MATERIALS AND METHODS}

\section{Sample collection}

Samples were collected prospectively, specifically for this research project, from patients seen at the Queen Elizabeth Hospital (Birmingham, UK), Mie University and Toyama Hospital (Japan). All patients gave informed consent for donating blood and the study procedure was approved by the South Birmingham Research Ethics Committee and the Institutional Review Board of Mie University and the Toyama Hospital of Japan. A standard operating procedure was applied to all blood collection and processing. Samples were collected in the fasting state, in the early morning before any surgery or medical treatment. Blood was allowed to clot at room temperature for $1-2 \mathrm{~h}$, centrifuged at $3000 \mathrm{~g}$ for $20 \mathrm{~min}$ and the serum collected and stored at $-80^{\circ} \mathrm{C}$ until processing.

Our gastric cancer cohort included consecutive patients with gastric and Siewert type III gastro-oesophageal junctional cancers (Siewert and Stein, 1998). Siewert type I and II gastro-oesophageal junctional cancers were excluded from the study. In the UK cohort, $87 \%$ of the cancers were in the upper third of the stomach, whereas in the Japanese cohort $22 \%$ were in the upper third, $35 \%$ in the middle and $43 \%$ in the lower third. In the United Kingdom, we collected samples from 90 patients with cancer and 152 control subjects and from Japan we collected 119 patients with cancer and 72 control subjects. Staging was based on the classification of the Japanese Gastric Cancer Association (Japanese Gastric Cancer, 1998) or that described by Siewert and Stein (1998). In both cases, stages 1 and 2 were considered as 'early' disease and stages 3 and 4 as 'late' disease. Control subjects were drawn from patients with upper gastrointestinal symptoms in whom endoscopy showed no evidence of malignant disease.

\section{Quantitation of MIF, DJ-1, H. pylori and CEA}

Serum samples were allocated to 96-well plates so that age, gender, study site (UK, Japan) and disease group (control, gastric cancer) were evenly distributed. The concentrations of MIF, DJ-1, H. pylori IgG and CEA were determined by sandwich ELISA according to the manufacturer's instructions (MIF and DJ-1: R\&D Systems, Minneapolis, MN, USA; H. pylori IgG: Demeditec Diagnostics GmbH, Kiel, Germany; and CEA: Fujirebio Diangostics, Goteberg, Sweden). All assays were run in the same laboratory at the University of Birmingham.

\section{Data analysis}

Mann-Whitney tests were used to determine significant differences in protein concentrations between patient groups. Receiver operator characteristic (ROC) analysis was used to assess biomarker potential. Logistic regression models were built using the multiple fractional polynomial (MFP) model selection procedures available in the MFP package (Royston and Altman, 1994), following the fractional polynomial model selection procedures using each protein individually.

\section{RESULTS}

\section{Serum MIF and DJ-1 in gastric cancer patients}

Serum MIF levels were significantly raised in Japanese patients with gastric cancer with a mean concentration of $1062 \mathrm{pg} \mathrm{ml}^{-1}$ in cancer patients compared with $285 \mathrm{pg} \mathrm{ml}^{-1}$ in the Japanese control group $(P<0.0001)$ (Figure $1 \mathrm{~A})$. Elevated serum MIF was seen in Japanese patients with both early and late stage disease (means of 870 and $1348 \mathrm{pg} \mathrm{ml}^{-1}$, respectively). In the Japanese cancer patients, MIF levels were not significantly influenced by the position of the tumour in the stomach (lower, middle or upper third of the stomach), age or gender.

In contrast to the $\sim 4$-fold elevation seen in Japanese patients, levels of MIF in the UK cancer group were only marginally raised relative to the UK control group (mean of 379 vs $312 \mathrm{pg} \mathrm{ml}^{-1}$, respectively), although this small increase was statistically significant $(P=0.0020)$. Levels of MIF in both groups of UK patients were similar to those of the Japanese control subjects and considerably lower than the levels in Japanese cancer patients (Figure 1A and Table 1).

Serum DJ-1 levels were significantly elevated in Japanese patients with gastric cancer with a mean concentration of
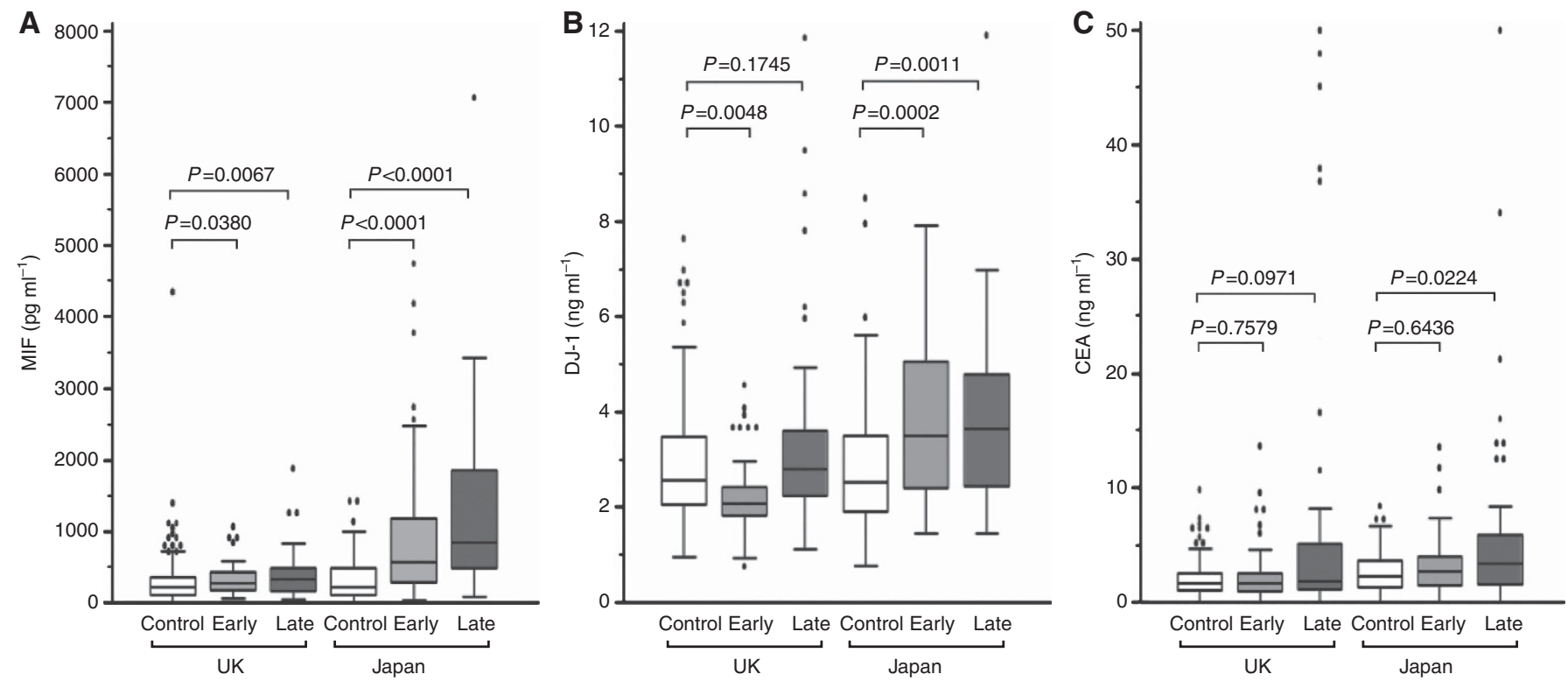

Figure I (A-C) Box and whiskers plot of the serum concentration of MIF, DJ-I and CEA in control, early stage cancer and late stage cancer samples from the UK and Japanese sample cohorts. 
$3.78 \mathrm{ng} \mathrm{ml}^{-1}$ in cancer patients compared with $2.85 \mathrm{ng} \mathrm{ml}^{-1}$ in the Japansese control group $(P<0.0001)$ (Figure $1 \mathrm{~B}$ and Table 1 ). Elevated serum DJ-1 was seen in Japanese patients with both early and late stage disease (means of 3.71 and $3.91 \mathrm{ng} \mathrm{ml}^{-1}$, respectively). As seen with MIF, no elevation of serum DJ-1 in gastric cancer was observed in the UK cohort (mean of 2.96 vs $2.90 \mathrm{ng} \mathrm{ml}^{-1}$ ) (Table 1). The concentration of DJ-1 in the early stage gastric cancer patients from the United Kingdom was actually slightly lower than the control cohort (mean of $2.30 \mathrm{ng} \mathrm{ml}^{-1}, P=0.0048$ ), and although the concentration in late stage patients was slightly higher, this was not statistically significant (mean of $3.42 \mathrm{ng} \mathrm{ml}^{-1}, P=0.1745$ ).

\section{Serum CEA and $H$. pylori in gastric cancer patients}

Carcinoembryonic antigen was significantly elevated in Japanese patients with late stage gastric cancer $(P=0.0224)$, but not early stage disease $(P=0.2258)$ (Figure $1 \mathrm{C}$ and Table 1$)$. Carcinoembryonic antigen was not statistically significantly elevated in UK gastric cancer patients with early stage disease $(P=0.7579)$, and although CEA levels $>10 \mathrm{ng} \mathrm{ml}^{-1}$ were observed in 7 of the 53 patients with late stage disease, across this patient group the increase did not reach statistical significance $(P=0.0971)$.

H. pylori IgG levels were measured in all subjects in this study. Positive results were obtained in $18 \%$ and $31 \%$ of the UK control and cancer cohorts, respectively, and $37 \%$ and $70 \%$ of the Japanese control and cancer cohorts, respectively. However, we found no evidence of any association between $H$. pylori and serum MIF; serum MIF was significantly elevated in Japanese gastric cancer patients regardless of $H$. pylori status (Figure 2).

\section{Assessment of biomarker potential}

Receiver operator characteristic curves for the discrimination between patients with and without gastric cancer were generated for MIF, DJ-1 and CEA. In the Japanese patients, MIF, DJ-1 and CEA generated areas under the ROC curve of $0.83,0.68$ and 0.58 ,

Table I Patient demographics

\begin{tabular}{|c|c|c|c|c|}
\hline Variable & $\begin{array}{c}\text { UK } \\
\text { controls }\end{array}$ & $\begin{array}{c}\text { UK } \\
\text { cancer }\end{array}$ & $\begin{array}{l}\text { Japan } \\
\text { controls }\end{array}$ & $\begin{array}{l}\text { Japan } \\
\text { cancer }\end{array}$ \\
\hline$N$ & 152 & 90 & 72 & 119 \\
\hline \multicolumn{5}{|l|}{ Stage } \\
\hline Early & - & 37 & - & 78 \\
\hline Late & - & 53 & - & 41 \\
\hline Age (years) & $59.9 \pm 14.3$ & $67.5 \pm 10.6$ & $55.0 \pm 16.5$ & $66.2 \pm 11.4$ \\
\hline \multicolumn{5}{|l|}{ Gender } \\
\hline Male & 70 & 66 & 37 & 84 \\
\hline Female & 82 & 24 & 35 & 35 \\
\hline \multicolumn{5}{|l|}{ H. pylori } \\
\hline Negative & 118 & 56 & 41 & 24 \\
\hline Borderline & 7 & 6 & 5 & 12 \\
\hline Positive & 27 & 28 & 26 & 83 \\
\hline $\mathrm{MIF}\left(\mathrm{pg} \mathrm{ml}^{-1}\right)$ & $312 \pm 415$ & $379 \pm 302$ & $286 \pm 282$ & $1063 \pm 1083$ \\
\hline DJ-I $\left(n g \mathrm{ml}^{-1}\right)$ & $2.9 \pm 1.3$ & $3.0 \pm 1.8$ & $2.8 \pm 1.4$ & $3.8 \pm 1.7$ \\
\hline CEA $\left(n g \mathrm{ml}^{-1}\right)$ & $2.0 \pm 1.6$ & $8.6 \pm 27.2$ & $2.8 \pm 2.1$ & $5.7 \pm 20.8$ \\
\hline
\end{tabular}

Abbreviations: $C E A=$ Carcinoembryonic antigen; $M I F=$ macrophage inhibitory factor. The number of individuals in each patient group, their age (mean and range) and gender are shown, along with $H$. pylori status. Serum MIF, DJ-I and CEA concentrations are presented as the means \pm s.d. for all patients with/without gastric cancer in the UK and Japanese arms of the study. respectively (Figure 3 ). In the UK patients, MIF, DJ-1 and CEA generated areas under the ROC curve of $0.62,0.52$ and 0.54 , respectively (Figure 4). Logistic regression was used to determine if the diagnostic utilities of MIF, DJ-1 and CEA could be used in combination. Model selection and Wald chi-squared test of deviance (compared with the null model that did not have any prediction variable) results are shown in Table 2. The model for the Japanese population was $(\log (P /(1-P)=-7.947+1.436 \times$ $\log (\mathrm{MIF}+0.1))$, where $P$ is the probability of having cancer, containing MIF but not CEA or DJ -1 . The model for the UK population was $\left(\log \left(P /(1-P)=-0.34-108 \times\left((\mathrm{MIF}+0.1)^{-1}\right)+\right.\right.$ $0.15 \times \mathrm{CEA})$, containing MIF and CEA, but not DJ-1.

\section{Evaluation of tissue DJ-1}

As DJ-1 has not previously been investigated as a marker of gastric malignancy, we used western blotting to investigate DJ-1 expression in gastric cancer tissue. DJ-1 levels were assessed in gastric tumour and adjacent normal tissue from eight different Japanese

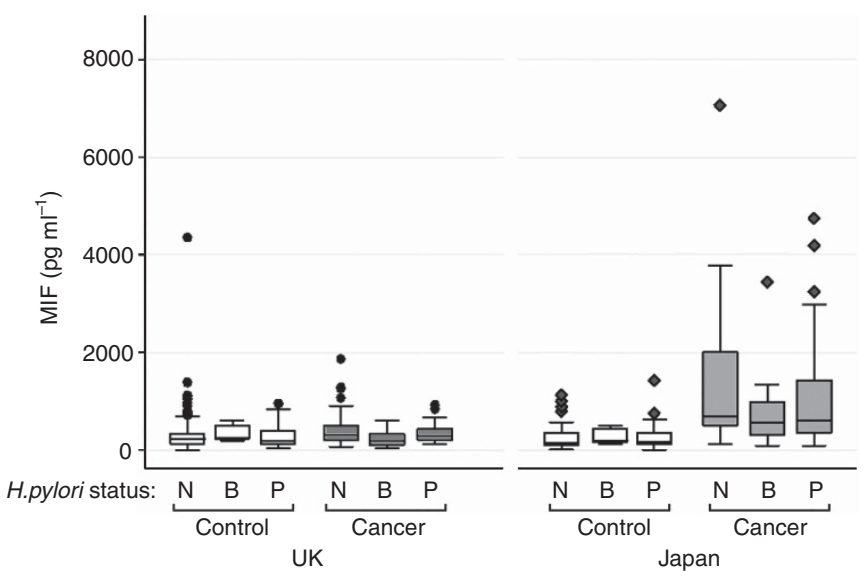

Figure 2 Box and whiskers plot of the serum concentration of MIF levels and classification of $\mathrm{H}$. pylori status, comparing controls and cancer samples from the UK and Japanese sample cohorts $(\mathrm{N}, \mathrm{B}$ and $\mathrm{P}=$ negative, borderline and positive $H$. pylori status respectively).

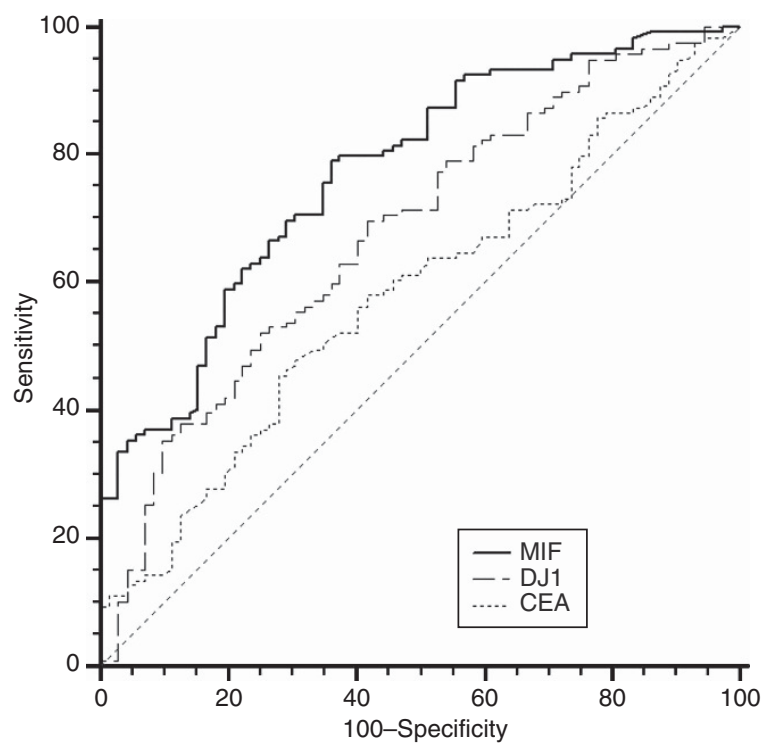

Figure 3 Receiver operator characteristic (ROC) curves of the serum concentration of MIF, DJ-I and CEA for Japanese samples (cancer vs control) 
cancer patients. In seven out of eight cases, the level of DJ-1 protein was substantially lower in the tumour tissue than the adjacent normal tissue (Figure 5).

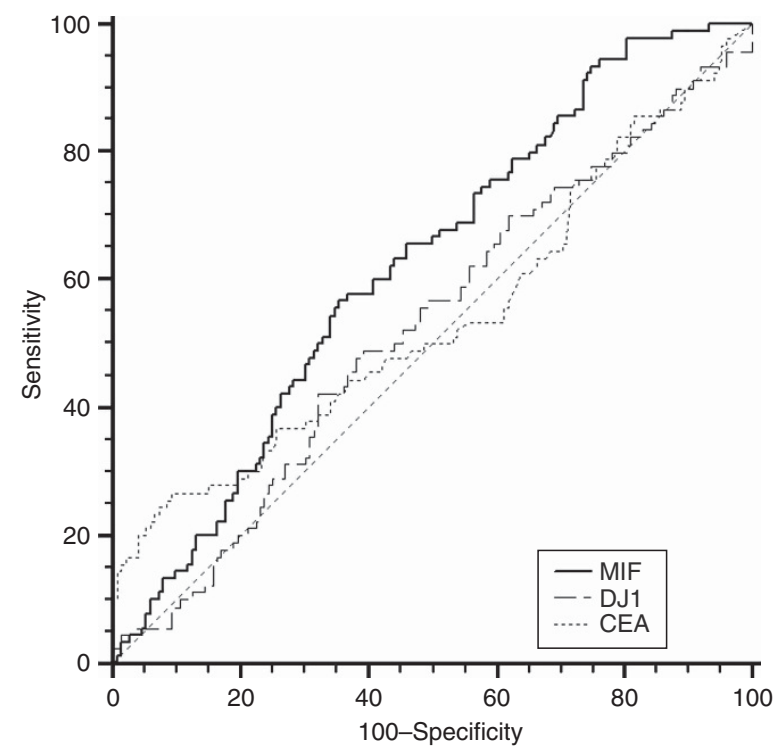

Figure 4 Receiver operator characteristic (ROC) curves of the serum concentration of MIF, DJ-I and CEA for UK samples (cancer vs control).

Table 2 Univariate logistic regression analysis of CEA, MIF and DJ-I in Japanese and UK study populations separately

\begin{tabular}{lcc} 
& Wald $\boldsymbol{\chi}^{\mathbf{2}} \boldsymbol{P}$-value (Japan) & Wald $\boldsymbol{\chi}^{\mathbf{2}} \boldsymbol{P}$-value (UK) \\
\hline CEA & Not selected & $<0.00$ I (linear) \\
DJ-I & $<0.00$ I (linear) & Not selected \\
MIF & $<0.001$ (log) & $<0.001$ (power to - I) \\
\hline
\end{tabular}

Abbreviations: $\mathrm{CEA}=$ Carcinoembryonic antigen; $\mathrm{MIF}=$ macrophage inhibitory factor.
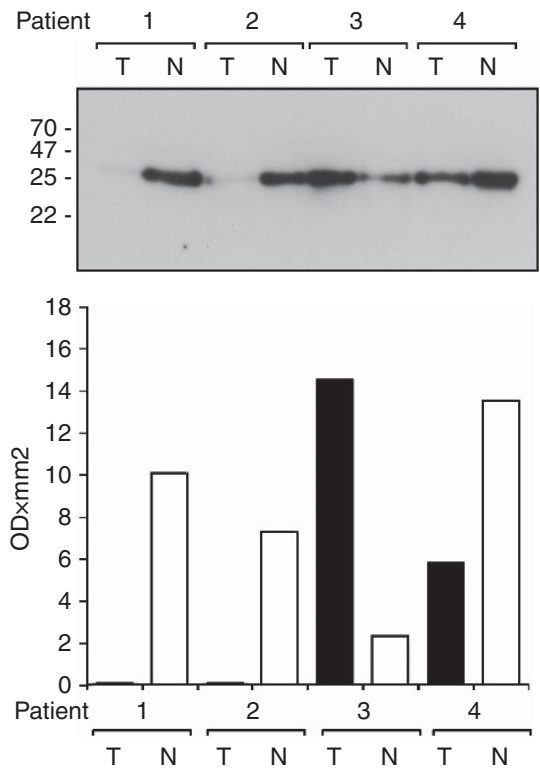

\section{DISCUSSION}

Strategies for gastric cancer biomarker discovery include the proteomic analysis of gastric cancer cell lines, gastric fluid, gastric cancer tissue and serum or plasma to identify aberrantly expressed or modified proteins. The list of candidate biomarkers proposed for gastric cancer is steadily increasing (Polanski and Anderson, 2007), although to date few have been validated in large patient cohorts. Potential biomarkers identified through proteomic analysis of blood include fibrinopeptide-A (Ebert et al, 2006), thrombin light chain A (Ebert et al, 2005b), complement component C9 (Chong et al, 2010) and apolipoproteins C-1 and C-III (Cohen et al, 2011). Alpha-1-antitrypsin, S100A9 and gastric intrinsic factor have been proposed as biomarkers in gastric fluid (Hsu et al, 2007; Wu et al, 2012), whereas alpha-defensins (Kim et al, 2010) and Cathepsin B (Ebert et al, 2005a) have been identified from tissue analysis. Other recently reported biomarkers include Reg-4, DKK-1 and sHLA-g (Kobayashi et al, 2010; Cao et al, 2011; Gomceli et al, 2012), circulating micro RNAs (Konishi et al, 2012; Song et al, 2012) and methylated tumour DNA (Zheng et al, 2011).

The fact that cancers can arise from different combinations of genetic and epigenetic abberrations (Yamashita et al, 2011) decreases the likelihood of a single protein being over/under expressed in every patient. Thus, a sensitive test for gastric cancer may require the measurement of several biomarkers. The biomarkers would ideally be measurable in blood, as blood is easily collected with little discomfort, relatively low cost and does not require expensive instrumentation or highly skilled personnel. To date, no protein biomarkers have gained FDA approval for gastric cancer detection. Carcinoembryonic antigen, gastrin and CA 19-9 have some diagnostic potential for gastric cancer (Ishigami et al, 2001; Triantafillidis et al, 2003), although they lack both sensitivity and specificity (Fletcher, 1986; Steinberg et al, 1986; Chevinsky, 1991).

DJ-1 was chosen for this study, as it was identified by mass spectrometry (along with MIF) as being secreted by gastric cancer cell lines (AGS, HGC-27 and CLS-145). Although DJ-1 has not previously been investigated as a biomarker for gastric cancer, there is strong evidence that MIF is intimately involved in the pathogenesis of the disease (Shun et al, 2005; He et al, 2006). It is apparent from our study that MIF and DJ-1 are significantly
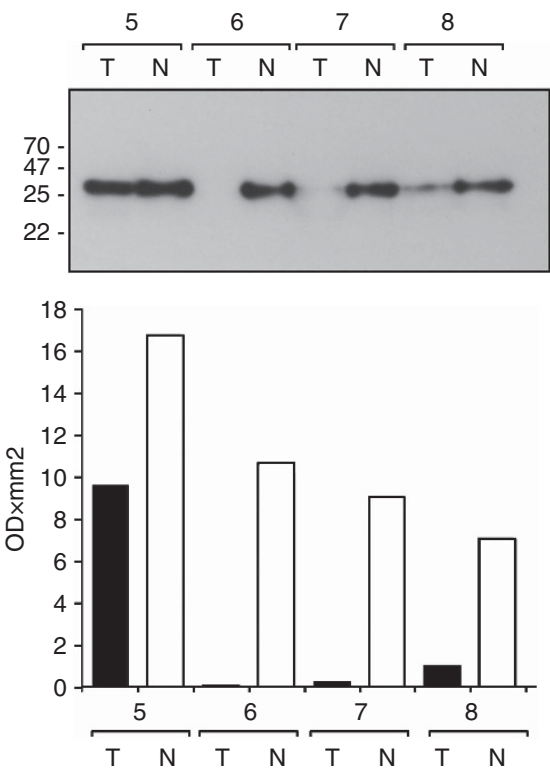

Figure 5 Western blots showing the expression of DJ-I in tumour $(T)$ and adjacent normal $(N)$ gastric tissue from 8 Japanese gastric cancer patients (an equal amount of total protein $(25 \mu \mathrm{g})$ from each tissue sample was used). Densitometric analysis of protein expression was measured as $\mathrm{OD} \times \mathrm{mm}{ }^{2}$. 
elevated in the serum of Japanese gastric cancer patients compared with Japanese control subjects, but these differences are far less pronounced in UK patients (Figure $1 \mathrm{~A}$ and $\mathrm{B}$ and Table 1). The concentration of MIF in the supernatant of gastric cancer cell lines has been reported to be elevated in numerous cell lines, in comparison with a control normal gastric cell line (He et al, 2006), and we find by proteomic analysis that MIF and DJ-1 are secreted by three different gastric cancer cell lines also (manuscript in preparation). This suggests that elevated levels of MIF and DJ-1 in the serum of gastric cancer patients could arise directly from secretion by their tumours. The regulatory role of elevated MIF expression in gastric cancer progression has been shown to be associated with angiogenesis, with increased numbers of microvessels in gastric cancer tissue that express high levels of MIF (Shun et al, 2005). There is evidence that micro RNAs may have a role in regulating MIF expression, particularly miR-451 (Bandres et al, 2009), which shows an inverse relationship with MIF mRNA and protein expression. The plasma levels of miR-451 and miR-486 have been shown to dramatically decrease post-operatively in a cohort of 56 Japanese gastric cancer patients (Konishi et al, 2012), and that initial plasma levels were much higher than healthy controls. They observed a correlation of high plasma levels with low gastric cancer tissue levels of miR-451. It appears that the secretion and expression dynamics of both MIF and miR-451 could be a possible explanation of high levels of MIF in the Japanese patients in our study (Figure 1A).

Our data show that MIF, DJ-1 and CEA have better areas under the ROC curve in areas of high incidence of gastric cancer (Figures 3 and 4). It has been previously shown that MIF and CEA together have greater diagnostic and prognostic potential in combination than when used separately (Camlica et al, 2008; Xia et al, 2009). Logistic regression analysis of our data show that the measurement of DJ-1 or CEA do not add to a model containing MIF in the Japanese cohort, but MIF and CEA are additive in the UK model (Table 2).

To examine the expression of DJ-1 within gastric tissue, western blots were performed to detect the level of DJ-1 in gastric tumour and adjacent normal tissue in Japanese patients diagnosed with gastric cancer (comparable Caucasian samples were not available). The level of DJ-1 was seen to be lower in seven out of the eight tumour tissue samples analysed and was barely detectable in four of them (Figure 5). One possible explanation for higher DJ-1 concentrations in the sera and lower concentrations in tumour tissue is that DJ-1 is secreted faster from tumour cells. Alternatively, both the lower levels in the tumour tissue and higher levels in serum may have other explanations. Our observation of lower DJ-1 levels in cancer tissue is mirrored by another study, where a lower amount of DJ-1 in breast cancer tissue relative to adjacent normal tissue was seen (Le Naour et al, 2001). In the same study, DJ-1 was detected by auto-antibodies present in the circulation of some breast cancer patients and DJ-1 itself was shown to have elevated serum levels in over one-third of the breast cancer patients tested. Additionally, DJ-1 was found to be secreted by the SUM- 44 breast cancer cell line (Le Naour et al, 2001). Most recently, a study of DJ-1 as a secretory molecule found that low levels of DJ-1 protein in invasive ductal carcinoma (IDC) breast tissue correlated with a higher level of DJ-1 mRNA (when compared with non-cancerous mammary gland) (Tsuchiya et al, 2012). In the same study, the breast cancer cell line MDA-MB-231

\section{REFERENCES}

Alberts SR, Cervantes A, van de Velde CJ (2003) Gastric cancer: epidemiology, pathology and treatment. Ann Oncol 14(Suppl 2): ii31-ii36

Bandres E, Bitarte N, Arias F, Agorreta J, Fortes P, Agirre X, Zarate R, DiazGonzalez JA, Ramirez N, Sola JJ, Jimenez P, Rodriguez J, Garcia-Foncillas J that secreted DJ-1 also showed low protein levels in the cells, implying that DJ-1 could be secreted from the IDC tissue. Most importantly, low DJ-1 protein levels in the cancerous cells of IDC cancer patients were found to correlate with significantly shorter disease-free survival (Tsuchiya et al, 2012). A proteomic study comparing the pancreatic juice secreted from patients with pancreatic ductal adenocarcinoma also found DJ-1 to be elevated in the pancreatic juice of cancer patients (Tian et al, 2008). This evidence supports our theory that DJ-1 is secreted by malignant tissues. To our knowledge, DJ-1 has not previously been reported to be elevated in the sera of gastric cancer patients.

Although $H$. pylori infection has been reported to increase serum MIF (Xia et al, 2005), other reports have shown little effect of $H$. pylori on circulating levels of MIF (He et al, 2006; Mohri et al, 2009 ) and $H$. pylori infection does not increase expression of MIF in gastric epithelium (Lebiedz et al, 2006). In our study, H. pylori infection appears not to be a contributory factor in raising MIF serum levels (Figure 2). The expression of MIF has been shown to increase the proliferation of gastric epithelial cells (Xia et al, 2005) and stimulation of gastric cancer cells with recombinant MIF increases proliferation and phosphorylation of Akt via the PI3K/ Akt pathway (Li et al, 2009). Similar proliferative effects of MIF have been seen in hepatocellular carcinoma tissue and cell lines and is thought to have a positive effect on cell invasion and migration (Ren et al, 2003). DJ-1 is also a positive regulator of Akt and mTOR and this has been shown to protect cells from hypoxiainduced death, through increased stability of HIF1, an important requirement for tumour survival (Vasseur et al, 2009). Recently it has been shown that p53 is a negative regulator of DJ-1 and that cell transformation coupled with loss of p53 expression leads to elevated levels of DJ-1(Vasseur et al, 2012). Macrophage inhibitory factor itself can bind to p53 and inhibit p53 function (Jung et al, 2008). It appears that overexpression of both MIF and DJ-1 may confer a survival advantage for a gastric tumour through increased proliferation, resistance to hypoxia-induced cell death and abrogation of $\mathrm{p} 53$ function.

It is widely assumed that Japanese gastric cancer is biologically different to western gastric cancer, and while incidence, association with $H$. pylori and position in the stomach are clearly different, few studies have compared the two types of tumour at the molecular level; some genetic and gene expression differences have been reported (Theuer et al, 2002; Ossandon et al, 2008). Our data add to this body of evidence suggesting fundamental differences between gastric cancer in Japan and the West. The careful study design allows us to exclude several trivial explanations. Differences due to sample preparation or assay performance are excluded by the use of a common standard operating procedure for serum preparation, the same assay kit, the same laboratory and similar disease classification and staging systems in both groups of patients. The novel identification of DJ-1 and further examination of MIF suggest both could have a role in gastric cancer diagnosis, particularly in areas of high incidence.

\section{ACKNOWLEDGEMENTS}

This work was funded by a University of Birmingham Knowledge Transfer Development Grant and Chugai Pharmaceutical Co. Ltd. DGW is funded by Birmingham Science City.

(2009) microRNA-451 regulates macrophage migration inhibitory factor production and proliferation of gastrointestinal cancer cells. Clin Cancer Res 15: 2281-2290

Bonifati V, Rizzu P, Squitieri F, Krieger E, Vanacore N, van Swieten JC, Brice A, van Duijn CM, Oostra B, Meco G, Heutink P (2003) 
DJ-1( PARK7), a novel gene for autosomal recessive, early onset parkinsonism. Neurol Sci 24: 159-160

Camlica H, Duranyildiz D, Oguz H, Oral EN, Yasasever V (2008) The diagnostic value of macrophage migration inhibitory factor (MIF) in gastric cancer. Pathol Oncol Res 14: 79-83

Cao M, Yie S, Liu J, Ye S, Xia D, Gao E (2011) Plasma soluble HLA-G is a potential biomarker for diagnosis of colorectal, gastric, esophageal and lung cancer. Tissue Antigen 78: 120-128

Chevinsky AH (1991) CEA in tumors of other than colorectal origin. Semin Surg Oncol 7: 162-166

Chong P, Lee H, Loh M, Choong L, Lin Q, So J, Lim K, Soo R, Yong W, Chan S, Smoot D, Ashktorab H, Yeoh K, Lim Y (2010) Upregulation of plasma C9 protein in gastric cancer patients. Proteomics 10: 3210-3221

Cohen M, Yossef R, Erez T, Kugel A, Welt M, Karpasas M, Bones J, Rudd P, Taieb J, Boissin H, Harats D, Noy K, Tekoah Y, Lichtenstein R, Rubin E, Porgador A (2011) Serum apolipoproteins C-I and C-III are reduced in stomach cancer patients: results from MALDI-based peptidome and immuno-based clinical assays. PLoS One 6: e14540

Ebert MP, Kruger S, Fogeron ML, Lamer S, Chen J, Pross M, Schulz HU, Lage H, Heim S, Roessner A, Malfertheiner P, Rocken C (2005a) Overexpression of cathepsin B in gastric cancer identified by proteome analysis. Proteomics 5: 1693-1704

Ebert MP, Lamer S, Meuer J, Malfertheiner P, Reymond M, Buschmann T, Rocken C, Seibert V (2005b) Identification of the thrombin light chain a as the single best mass for differentiation of gastric cancer patients from individuals with dyspepsia by proteome analysis. J Proteome Res 4: $586-590$

Ebert MP, Niemeyer D, Deininger SO, Wex T, Knippig C, Hoffmann J, Sauer J, Albrecht W, Malfertheiner P, Rocken C (2006) Identification and confirmation of increased fibrinopeptide a serum protein levels in gastric cancer sera by magnet bead assisted MALDI-TOF mass spectrometry. J Proteome Res 5: 2152-2158

Fletcher RH (1986) Carcinoembryonic antigen. Ann Intern Med 104: 66-73

Gomceli I, Bostanci E, Ozer I, Kemik A, Turhan N, Tez M, Kilic S, Demiriz B, Akoglu M (2012) A novel screening biomarker in gastric cancer: serum dickkopf-1. Hepatogastroenterology 59: 1661-1664

Guo JF, Xiao B, Liao B, Zhang XW, Nie LL, Zhang YH, Shen L, Jiang H, Xia K, Pan Q, Yan XX, Tang BS (2008) Mutation analysis of Parkin, PINK1, DJ-1 and ATP13A2 genes in Chinese patients with autosomal recessive early-onset Parkinsonism. Mov Disord 23: 2074-2079

He XX, Yang J, Ding YW, Liu W, Shen QY, Xia HH (2006) Increased epithelial and serum expression of macrophage migration inhibitory factor (MIF) in gastric cancer: potential role of MIF in gastric carcinogenesis. Gut 55: 797-802

Hsu P, Chen C, Hsieh C, Chang W, Lai K, Lo G, Hsu P, Tsay F, Chen Y, Hsiao M, Chen H, Lu P (2007) Alphal-antitrypsin precursor in gastric juice is a novel biomarker for gastric cancer and ulcer. Clin Cancer Res 13: $876-883$

Ishigami S, Natsugoe S, Hokita S, Che X, Tokuda K, Nakajo A, Iwashige H, Tokushige M, Watanabe T, Takao S, Aikou T (2001) Clinical importance of preoperative carcinoembryonic antigen and carbohydrate antigen 19-9 levels in gastric cancer. J Clin Gastroenterol 32: 41-44

Japanese Gastric Cancer A (1998) Japanese Classification of Gastric Carcinoma - 2nd English Edition. Gastric Cancer 1: 10-24

Jemal A, Siegel R, Ward E, Murray T, Xu J, Thun MJ (2007) Cancer statistics, 2007. CA Cancer J Clin 57: 43-66

Jung H, Seong HA, Ha H (2008) Critical role of cysteine residue 81 of macrophage migration inhibitory factor (MIF) in MIF-induced inhibition of p53 activity. J Biol Chem 283: 20383-20396

Kim H, Reyzer M, Choi I, Kim C, Kim H, Oshima A, Chertov O, Colantonio S, Fisher R, Allen J, Caprioli R, Green J (2010) Gastric cancer-specific protein profile identified using endoscopic biopsy samples via MALDI mass spectrometry. J Proteome Res 9: 4123-4130

Kobayashi Y, Niwa Y, Tajika M, Kawai H, Kondo S, Hara K, Mizuno N, Hijioka S, Sawaki A, Matsuo K, Nakagawa H, Nakamura Y, Yamao K (2010) Serum tumor antigen REG4 as a useful diagnostic biomarker in gastric cancer. Hepatogastroenterology 57: 1631-1634

Konishi H, Ichikawa D, Komatsu S, Shiozaki A, Tsujiura M, Takeshita H, Morimura R, Nagata H, Arita T, Kawaguchi T, Hirashima S, Fujiwara H, Okamoto K, Otsuji E (2012) Detection of gastric cancer-associated microRNAs on microRNA microarray comparing pre- and postoperative plasma. Br J Cancer 106: 740-747

Le Naour F, Misek DE, Krause MC, Deneux L, Giordano TJ, Scholl S, Hanash SM (2001) Proteomics-based identification of RS/DJ-1 as a novel circulating tumor antigen in breast cancer. Clin Cancer Res 7: 3328-3335
Lebiedz P, Heidemann J, Lugering A, Riedel S, Herbst H, Domschke W, Kucharzik T, Maaser C (2006) Gastric epithelial expression of macrophage migration inhibitory factor is not altered by Helicobacter pylori infection in humans. Helicobacter 11: 258-265

Li GQ, Xie J, Lei XY, Zhang L (2009) Macrophage migration inhibitory factor regulates proliferation of gastric cancer cells via the PI3K/Akt pathway. World J Gastroenterol 15: 5541-5548

Mo J, Jung J, Yoon J, Hong J, Kim M, Ann E, Seo M, Choi Y, Park H (2010) DJ-1 modulates the p38 mitogen-activated protein kinase pathway through physical interaction with apoptosis signal-regulating kinase 1 . J Cell Biochem 110: 229-237

Mohri Y, Mohri T, Wei W, Qi YJ, Martin A, Miki C, Kusunoki M, Ward DG, Johnson PJ (2009) Identification of macrophage migration inhibitory factor and human neutrophil peptides $1-3$ as potential biomarkers for gastric cancer. Br J Cancer 101: 295-302

Nagakubo D, Taira T, Kitaura H, Ikeda M, Tamai K, Iguchi-Ariga SM, Ariga H (1997) DJ-1, a novel oncogene which transforms mouse NIH3T3 cells in cooperation with ras. Biochem Biophys Res Commun 231: 509-513

Ossandon F, Villarroel C, Aguayo F, Santibanez E, Oue N, Yasui W, Corvalan A (2008) In silico analysis of gastric carcinoma Serial Analysis of Gene Expression libraries reveals different profiles associated with ethnicity. Mol Cancer 7: 1-9

Polanski M, Anderson NL (2007) A list of candidate cancer biomarkers for targeted proteomics. Biomark Insights 1: 1-48

Ren Y, Tsui HT, Poon RT, Ng IO, Li Z, Chen Y, Jiang G, Lau C, Yu WC, Bacher M, Fan ST (2003) Macrophage migration inhibitory factor: roles in regulating tumor cell migration and expression of angiogenic factors in hepatocellular carcinoma. Int J Cancer 107: 22-29

Royston P, Altman D (1994) Regression using fractional polynomials of continuous covariates. Appl Stat 3: 429-467

Shun CT, Lin JT, Huang SP, Lin MT, Wu MS (2005) Expression of macrophage migration inhibitory factor is associated with enhanced angiogenesis and advanced stage in gastric carcinomas. World $J$ Gastroenterol 11: 3767-3771

Siewert JR, Stein HJ (1998) Classification of adenocarcinoma of the oesophagogastric junction. Br J Surg 85: 1457-1459

Song M, Pan K, Su H, Zhang L, Ma J, Li J, Yuasa Y, Kang D, Kim Y, You W (2012) Identification of serum microRNAs as novel noninvasive biomarkers for early detection of gastric cancer. PLoS One 7: e33608

Steinberg WM, Gelfand R, Anderson KK, Glenn J, Kurtzman SH, Sindelar WF, Toskes PP (1986) Comparison of the sensitivity and specificity of the CA19-9 and carcinoembryonic antigen assays in detecting cancer of the pancreas. Gastroenterology 90: 343-349

Taira T, Saito Y, Niki T, Iguchi-Ariga S, Takahashi K, Ariga H (2004) DJ-1 has a role in antioxidative stress to prevent cell death. EMBO Rep 5: 213-218

Theuer C, Campbell B, Peel D, Lin F, Carpenter P, Ziogas A, Butler J (2002) Microsatellite instability in Japanese vs European American patients with gastric cancer. Arch Surg 137: 960-965

Tian M, Cui YZ, Song GH, Zong MJ, Zhou XY, Chen Y, Han JX (2008) Proteomic analysis identifies MMP-9, DJ-1 and A1BG as overexpressed proteins in pancreatic juice from pancreatic ductal adenocarcinoma patients. BMC Cancer 8: 241

Triantafillidis JK, Merikas E, Govosdis V, Konstandellou E, Cheracakis P, Barbatzas C, Tzourmakliotis D, Peros G (2003) Increased fasting serum levels of growth hormone and gastrin in patients with gastric and large bowel cancer. Hepatogastroenterology 50(Suppl 2): cclvi-cclx

Tsuchiya B, Iwaya K, Kohno N, Kawate T, Akahoshi T, Matsubara O, Mukai K (2012) Clinical significance of DJ-1 as a secretory molecule: retrospective study of DJ-1 expression at mRNA and protein levels in ductal carcinoma of the breast. Histopathology 61: 69-77

Vasseur S, Afzal S, Tardivel-Lacombe J, Park DS, Iovanna JL, Mak TW (2009) DJ-1/PARK7 is an important mediator of hypoxia-induced cellular responses. Proc Natl Acad Sci USA 106: 1111-1116

Vasseur S, Afzal S, Tomasini R, Guillaumond F, Tardivel-Lacombe J, Mak T, Iovanna J (2012) Consequences of DJ-1 upregulation following p53 loss and cell transformation. Oncogene 31: 664-670

Wu W, Juan W, Liang C, Yeoh K, So J, Chung M (2012) S100A9, GIF and AAT as potential combinatorial biomarkers in gastric cancer diagnosis and prognosis. Proteomics Clin Appl 6: 152-162

Xia HH, Lam SK, Chan AO, Lin MC, Kung HF, Ogura K, Berg DE, Wong BC (2005) Macrophage migration inhibitory factor stimulated by 
Helicobacter pylori increases proliferation of gastric epithelial cells. World J Gastroenterol 11: 1946-1950

Xia HH, Yang Y, Chu KM, Gu Q, Zhang YY, He H, Wong WM, Leung SY, Yuen ST, Yuen MF, Chan AO, Wong BC (2009) Serum macrophage migration-inhibitory factor as a diagnostic and prognostic biomarker for gastric cancer. Cancer 115: 5441-5449
Yamashita K, Sakuramoto S, Watanabe M (2011) Genomic and epigenetic profiles of gastric cancer: potential diagnostic and therapeutic applications. Surg Today 41: 24-38

Zheng Y, Chen L, Li J, Yu B, Su L, Chen X, Yu Y, Yan M, Liu B, Zhu Z (2011) Hypermethylated DNA as potential biomarkers for gastric cancer diagnosis. Clin Biochem 44: 1405-1411

This work is published under the standard license to publish agreement. After 12 months the work will become freely available and the license terms will switch to a Creative Commons Attribution-NonCommercial-Share Alike 3.0 Unported License. 